\title{
The Trends and Level of Urbanization in Eastern Uttar Pradesh
}

\author{
Dr. (Mrs.) Kiran Kumari \\ Associate Professor, Department of Geography Rajiv Gandhi University, Rono Hills, Arunachal Pradesh- \\ 791112
}

\begin{abstract}
This paper assess the changing trends and level of urbanization in Eastern Uttar Pradesh which is based primarily on statistical analysis of the census data for all the decennial census counts beginning with 1901. The present century has witnessed a trend of increasing urbanization coupled with the urban growth of individual towns.

The urban population of the study area has increased by more than six times during ten decades of the present century. The progress of urbanization has been inconsistent; the level has increased from 6.70 per cent in 1901 to 11.74 percent in 2001.

In the study area the percentage growth of the total population is 262.97 per cent while urban population increased by 535.93 per cent during 100 years of the present century. When the urban population is viewed separately in terms of size classes, variations in rate of growth of various size of towns become quite clear. The number of towns in Class I has increased from 2 to 14 or from 2.44 per cent to 6.93 per cent in 1901-2001. Class I town's share 54.61 per cent of the total urban population of the study area in 2001. The concentration of 54.61 per cent of urban population in only 6.93 per cent of the total towns clearly reveals the imbalance in the distribution of urban population in various size classes.
\end{abstract}

Key words: urban growth; urbanization; size-class; urban area

\section{Introduction}

The study of urban growth pattern helps us to understand the stages of urban development as well as urban environment in a country and the differential growth rates show the extent of rural to urban migration. The present century has witnessed a trend of increasing urbanization coupled with the urban growth of individual towns. Urbanization and urban growth are phenomena of increasing concern to both planners and policy makers alike since trends and patterns of urbanization have wide ranging implications on socio-economic development. In general the urban population change occurs as a result of the interaction of spatial and demographic phenomena.

In simple term urbanization is the shift from a rural to an urban society, and involves an increase in the number of people in urban areas during a particular year. Urbanization is an index of transformation from traditional rural economies to modern industrial one. Urbanization is a progressive concentration of population in urban unit (Davis, 1965). Urbanization may take place as a result of an expansion of the boundaries of an urban area or of a reclassification of areas as urban according to pre-determined criteria. Growth in urban population may take place because of the consequent growth of an urban place as a result of the above two reasons, or because of a natural increase and net migration.

During the past decades, both scale and pattern of urban growth in Eastern Uttar Pradesh were transformed continuously and with increasing rapidity. Like many other regions, the growth of the urban population in Eastern Uttar Pradesh was much rapid than that of the population growth in rural areas. The extent of growth in some urban centres was not just seen within their legal boundaries but had led to a spillover of the population into their peripheries. This situation can be attributed to two factors; firstly the availability of vast employment opportunities which drew migrants from the rural areas to settle in these peripheries and, secondly, the population moving away from the densely populated urban core centre's to settle in the outer limits of their urban boundaries.

\section{Aim of the Study}

This paper tries to highlight the process of urbanization in Eastern Uttar Pradesh with emphasis on trend, level and tempo of urbanization and urban population growth rate by size-classes using Census data of Uttar Pradesh during 1901-2001. 


\section{Indian Census Definition of Urban Areas}

In India, the census of definitions of 'concept of Urban Area' remained more or less the same for the period 1901-1951 and it was only in 1961 the several modifications were introduced to make the definition more satisfying from the statistical point of view. In 1981 census 'urban' was determined on the basis of number of empirical test; (a) a density of not less than 1000 per square mile (b) a population of 5,000 (c) threeforth of the occupations of the working population should be outside of agriculture; and (d) the place should have according to the superintendent of the State a few pronounced urban characteristics and amenities, the definition of which although leaving room for vagueness and discretion, yet meant to cover newly founded industrial areas, large housing settlements or tourist importance which have been recently served with all civic amenities.

The Census of India, 2001 the adopted the definition of 'urban area' is as follows:

a. Statutory Towns: All places with a municipality, corporation, cantonment board or notified town area committee etc. so declared by state law.

b. Census Towns: Places which satisfy following criteria.

i. Minimum population of 5000 .

ii. At least 75 per cent of male working population engaged in non-agricultural pursuits; and

iii. A density of population at least 400 persons per sq. km.

All areas which are not urban are-by definition-are rural. (Bhende \& Kanitkar,2006)

The Census of India has divided the urban areas into six categories in accordance to their population i.e. the Size-Class introduced first in 1961.

Class I Cities with a population of 100,000 and above; Class II towns with a population of 50,00099,999; Class III towns with a population of 20,000-49,999; Class IV towns with a population of 10,00019,999; Class V towns with a population of 5,000-9,999 and Class VI towns with a population of not less than 5000 .

\section{Trends of Urbanization}

India shares most characteristic features of urbanization in the developing countries. Number of urban agglomeration /town has grown from 82 in 1901 to 202 in 2001. Number of total population has increased from 1.8 crores in 1901 to 66.6 crores in 2001 whereas number of population residing in urban areas has increased from 12.3 lakh in 1901 to 78.2 lakh in 2001. The process of urbanization in Eastern U.P. is shown in Table-1. It reflects a gradual increasing trend of urbanization.

The urban population of the study area has increased by more than six times during ten decades of the present century i.e., increased from 1230221 in 1901 to 7823303 in 2001. The progress of urbanization has been inconsistent; the level has increased from 6.70 per cent in 1901 to 11.74 percent in 2001 . The present century has witnessed a trend of increasing urbanization coupled with the urban growth of individual towns.

\section{Level of Urbanization}

The degree or level of urbanization is defined as relative number of people who live in urban areas. Percent urban $\left[(\mathrm{U} / \mathrm{P})^{*} 100\right]$ and percent rural $\left[(\mathrm{R} / \mathrm{P})^{*} 100\right.$ and urban-rural ratio[(U/R)*100 ] are used to measure degree of urbanization. These are most commonly used for measuring degree of urbanization.

The degree of urbanization in Eastern Uttar Pradesh has always been lower (6.70 per cent) than Uttar Pradesh (11.32 percent) as a whole in 1901. After that going through many fluctuations the proportion of urban population in the study area recorded 11.74 percent and Uttar Pradesh figures 19.48 per cent as shown in Table 2.

From Table 3 it is clear that percent urban has increased from 7\% in 1901 to $12 \%$ in 2001, whereas percent rural has shown gradual decrease from $93 \%$ to $88 \%$ over a century. Urban-rural ratio which is a simple index measuring number of urbanites for each rural person in an areal unit experiences an increasing trend during hundred years in the process of urbanization in Eastern U.P. The urban-rural ratio for Eastern U.P. in 2001 turns out to be around 13, meaning that against every 100 ruralites there are 13 urbanites in Eastern U.P in 2001. All these indices pin point that Eastern U.P is in the process of urbanization (Sovani, 1966) and it is at the acceleration stage of urbanization.

\section{Tempo of Urbanization}

Tempo of urbanization refers to speed of urbanization and is measured as change registered in the level or degree of urbanization over the years. The growth of rural population has been fluctuating since 1901 but the percentage of annual exponential growth rate of urban population in Eastern U.P. it grew at faster pace from the decade 1921-31 to until 1941 as shown in Table 4. Thereafter it registered a sharp drop during the decade 193141. The decades1941-51 showed a significant improvement in the growth. The sharp drop in urban rate during 1951-61 was mainly due to declassification of a very large number of towns during that period. 
As depicted in table 5 it is clear that tempo or speed of urbanization is not uniform over the years. It shows a fluctuating trend over the years 1901-1981-1991 and a declining trend during 1991-2001. Again it is required to mention tempo of urbanization measured as a percent will tend toward zero as the urban population reaches the 100 percent level, since the urban and total population growth would become the same.

Tempo of $\mathrm{PU}=1 / \mathrm{n}[1 \mathrm{n}(\mathrm{PU} \mathrm{t}+\mathrm{n} / \mathrm{PU} \mathrm{t})]^{*} 100$, where $1 \mathrm{n}=$ natural $\log , \mathrm{PU} \mathrm{t}+\mathrm{n}$ and $\mathrm{PU} \mathrm{t}=$ percent urban in $t+n^{\text {th }}$ census and $t^{\text {th }}$ census respectively, $n=$ census interval $=10$. *Tempo of PR $=1 / n[1 \mathrm{n}(\mathrm{PR} t+n / P R t$ ) $]^{*} 100$, where $1 \mathrm{n}=$ natural $\log , \mathrm{PR} \mathrm{t}+\mathrm{n}$ and $\mathrm{PR} \mathrm{t}=$ percent urban in $\mathrm{t}+\mathrm{n}^{\text {th }}$ and $\mathrm{t}^{\text {th }}$ census respectively, $\mathrm{n}=$ census interval $=10$

\section{Urban Population Growth Rate by Size Classes}

The proportion of urban population to total population is considered as a crude indicator of urbanization to analyze the distribution of population by size class of towns in order to identify the trends of urbanization (Sovam, 1966; p.34-35). When the urban population is viewed separately in terms of size classes, variations in rate of growth of various size of towns become quite clear.

Table 6 provides an overview of the uneven distribution of the percentage of urban population as well as of the number of towns, and percentage of towns in various size classes during 1901-2001. The number of towns in Class I has increased from 2 to 14 or from 2.44 per cent to 6.93 per cent in 1901-2001. The predominance of Class I towns on urban scene since, 1961 is quite apparent. It had 55.39 per cent of the total urban population in 1961 as against 31.48 per cent in 1901. Class I town's share 54.61 per cent of the total urban population of the study area in 2001. The concentration of 54.61 per cent of urban population in only 6.93 per cent of the total towns clearly reveals the imbalance in the distribution of urban population in various size classes.

The number of towns in Class II has slightly increased from 3 to 9 or from 3.66 per cent to 4.46 of the total towns during 1901-2001 whereas the proportion of the population ha declined from 16.73 to 8.25 per cent during the same period. The number of Class III towns has sharply increased from 3 in 1901 to 48 in 2001 and the corresponding percentage has grown from 3.66 to 23.76 per cent while the percentage share of urban population was 8.90 in 1901 to 17.09 per cent in 2001. The population of Class IV towns has declined from 18.12 per cent of the total urban population in 1901 to 16.58 percent in 2001 , though the number of towns in this category has increased from 16 to 94 during the same period. Passing through many fluctuations, the percentage share of this class has increased from 19.51 per cent of the total towns in 1901 to 46.53 percent in 2001. The number of Class V towns, the percentage share to total towns has always been the largest during 1901-1991, the largest share in 2001, however, is owned by Class IV towns i.e., 46.34 per cent. The percentage share of population has decreased from 17.56 per cent in 1901 to 3.25 percent in 2001 . All the three indices have conspicuously declined in the case of Class IV towns. The number of towns has gone down from 29 to in 1901 to mere 4 in 2001. Their percentage in total towns has shrunk from 35.37 per cent to 1.08 per cent, while the percentage of population has declined from 7.57 to 0.22 per cent during 1901-2001.

Thus, the percentage of population covered by Class II, IV, V and VI towns has considerably gone down. Table 6, highlights the trend of urbanization in Eastern Uttar Pradesh in the present century, and indicates clearly that the concentration of population has been continuously increasing in Class I and Class III towns mainly due to in-migration as the rate of natural growth in these towns is lower than the towns of other categories.

\section{Conclusion}

Urbanization is followed by some basic problems in the field of housing, slums, transport, water supply and sanitation, water pollution and air pollution, inadequate provision for social infrastructure (school, hospital, etc). Thus our Cities are suffering from housing shortage, urban poverty, unemployment, crisis in urban infra-structural services this cities can not absorb these distressed rural migrants i.e. poor landless illiterate and unskilled agricultural labourers. Hence, this migration to urban class I cities causes' urban crisis more acute.

To build strong economic sector in the urban economy, growth efforts and investments should be directed towards small and medium cities which have been neglected so far so that functional base of urban economy is strengthened. There should be a mechanism for sustainable urban environmental management so that that the urban environment will be supportive to the needs of a rapidly increasing urban population. The urbanization is always a supportive force for economic and social development and it should be welcomed, indeed we must seek out creative and sustainable ways to accelerate it in the interest of both common masses and our environment. 


\section{References}

[1]. Bhende, A.A. and Kanitkar, T. (2006) Components Principles of Population Studies, Himalaya Publishing House, pp. 403-404

[2]. Davis, K. (1965). The urbanization of the human population. Scientific American, 213(3), 41-53.

[3]. Kumari, Kiran (2008), “Urbanization and Regional Development in Eastern Uttar Pradesh” Ph.D. Thesis, Chapter3, p. 85-94.

[4]. Kundu,A. Sarangi,N. Dash,B.P (2003)Rural Non-Farm Employment : An Analysis of RuralUrban Interdependence , Working Paper, 196, Overseas Development Institute, London.

[5]. Occasional paper No. 1 of 1993, Registrar General, New Delhi

[6]. Ramchandran, R. (1989), "Urbanization and Urban Systems in India”, Oxford University Press 989, Oxford India Paperbacks 1991, Chapter 1, p. 1.

[7]. Registrar General (1991) Census of India , Emerging Trends of Urbanisation in India,

[8]. Registrar General, 2001: Census of India, 2001, India, 2A, Mansingh Road, New Delhi110011, 25th July, 2001

[9]. Sovani, N. V. (1966): Urbanisation and Urban India, Asia Publishing House, Bombay

[10]. United Nations (1993) World Urbanisation Prospects- The 1992 Revision ,United Nations.New Work.

Table 1

Level of Urbanization in Eastern Uttar Pradesh (1901-2001)

\begin{tabular}{|c|c|c|c|c|c|c|c|}
\hline $\begin{array}{c}\text { Census } \\
\text { Year }\end{array}$ & $\begin{array}{c}\text { Number } \\
\text { of } \\
\text { Towns }\end{array}$ & $\begin{array}{c}\text { Total } \\
\text { Population } \\
\text { Population }\end{array}$ & & Growth & $\begin{array}{c}\text { Growth } \\
\text { in } \%\end{array}$ & $\begin{array}{c}\text { Proportion of } \\
\text { urban } \\
\text { population to } \\
\text { total }\end{array}$ & $\begin{array}{c}\text { Rate of } \\
\text { Urbanization }\end{array}$ \\
\hline 1901 & 82 & 18351556 & 1230221 & - & - & 6.70 & - \\
\hline 1911 & 79 & 18163589 & 1039703 & -190518 & -15.49 & 5.72 & -0.98 \\
\hline 1921 & 89 & 17563415 & 1082496 & 42793 & 4.12 & 6.16 & 0.44 \\
\hline 1931 & 94 & 26146890 & 1268040 & 185544 & 17.14 & 4.85 & -1.31 \\
\hline 1941 & 94 & 22903323 & 1533173 & 265133 & 20.91 & 6.69 & 1.84 \\
\hline 1951 & 97 & 23552816 & 1874294 & 341121 & 22.25 & 7.96 & 1.26 \\
\hline 1961 & 56 & 28290141 & 2125616 & 251322 & 13.41 & 7.51 & -0.44 \\
\hline 1971 & 75 & 33170866 & 2751489 & 625873 & 29.44 & 8.29 & 0.78 \\
\hline 1981 & 166 & 41651871 & 4407774 & 1656285 & 60.20 & 10.58 & 2.29 \\
\hline 1991 & 179 & 50296971 & 6078131 & 1670357 & 37.90 & 12.08 & 1.50 \\
\hline 2001 & 202 & 66610755 & 7823303 & 1745172 & 28.71 & 11.74 & -0.34 \\
\hline
\end{tabular}

Source : Compiled from various Census Reports

Table 2

Level of Urbanization in Eastern U.P. and U.P (1901-2001)

\begin{tabular}{|c|c|c|}
\hline \multirow{2}{*}{$\begin{array}{c}\text { Census } \\
\text { Year }\end{array}$} & $\begin{array}{c}\text { Eastern U.P. } \\
\text { Potal Pop. }\end{array}$ & $\begin{array}{c}\text { U. P. } \\
\text { Poportion of Urban to Total Pop. }\end{array}$ \\
\hline 1901 & 6.7 & 11.32 \\
\hline 1911 & 5.72 & 10.38 \\
\hline 1921 & 6.16 & 10.75 \\
\hline 1931 & 4.85 & 11.41 \\
\hline 1941 & 6.69 & 12.67 \\
\hline 1951 & 7.96 & 13.82 \\
\hline 1961 & 7.51 & 12.98 \\
\hline 1971 & 8.29 & 14.11 \\
\hline 1981 & 10.58 & 18.09 \\
\hline 1991 & 12.08 & 19.94 \\
\hline 2001 & 11.74 & 19.48 \\
\hline $\begin{array}{l}\text { Source : Census of India, 2001, Uttar Pradesh, Volume-I, } \\
\text { Primary Census }\end{array}$ & \\
\hline
\end{tabular}

Table 3

Level of Urbanization in Eastern Uttar Pradesh

\begin{tabular}{|l|c|c|c|}
\hline Census & Percent of & Percent of & Ratio of \\
\hline Year & $\begin{array}{c}\text { Urban } \\
\text { Population }\end{array}$ & $\begin{array}{c}\text { Rural } \\
\text { Population }\end{array}$ & $\begin{array}{c}\text { Urban-Rural } \\
\text { Population }\end{array}$ \\
\hline 1901 & 6.70 & 93.30 & 7.19 \\
\hline 1911 & 5.72 & 94.28 & 6.07 \\
\hline 1921 & 6.16 & 93.84 & 6.57 \\
\hline 1931 & 4.85 & 95.15 & 5.10 \\
\hline 1941 & 6.69 & 93.31 & 7.17 \\
\hline 1951 & 7.96 & 92.04 & 8.65 \\
\hline 1961 & 7.51 & 92.49 & 8.12 \\
\hline 1971 & 8.29 & 91.71 & 9.05 \\
\hline 1981 & 10.58 & 89.42 & 11.83 \\
\hline 1991 & 12.08 & 87.92 & 13.75 \\
\hline 2001 & 11.74 & 88.26 & 13.31 \\
\hline \multicolumn{4}{|l|}{ Source : Census of India, 2001, Uttar Pradesh, Volume-I, } \\
Primary Census & \multicolumn{4}{|l}{} \\
\hline
\end{tabular}


The Trends and Level of Urbanization in Eastern Uttar Pradesh

Table 4

Annual Growth Rate of Population in Eastern Uttar Pradesh (19012001)

\begin{tabular}{|c|c|c|c|}
\hline Census & $\begin{array}{c}\text { Annual Growth } \\
\text { Rate Percent }\end{array}$ & $\begin{array}{c}\text { Annual } \\
\text { Growth Rate } \\
\text { Percent } \\
\text { Year }\end{array}$ & $\begin{array}{c}\text { Annual } \\
\text { of Total } \\
\text { Population } \\
\text { Percent }\end{array}$ \\
\hline $1901-1911$ & -0.10 & -1.83 & $\begin{array}{c}\text { of Rural } \\
\text { Population }\end{array}$ \\
\hline $1911-1921$ & -0.34 & 0.4 & -0.001 \\
\hline $1921-1931$ & 3.28 & 1.46 & 3.38 \\
\hline $1931-1941$ & -1.42 & 1.73 & -1.64 \\
\hline $1941-1951$ & 0.28 & 1.82 & 0.14 \\
\hline $1951-1961$ & 1.67 & 1.18 & 1.71 \\
\hline $1961-1971$ & 1.47 & 2.27 & 1.4 \\
\hline $1971-1981$ & 2.04 & 3.76 & 1.83 \\
\hline $1981-1991$ & 1.72 & 2.75 & 1.58 \\
\hline $1991-2001$ & 2.45 & 2.23 & 2.48 \\
\hline $\begin{array}{l}\text { Source : Census of India, 2001, Uttar Pradesh, Volume-I, Primary } \\
\text { Census }\end{array}$ & & \\
\hline
\end{tabular}

Table 5

Tempo of Urbanization in Eastern U.P.

\begin{tabular}{|c|c|c|}
\hline Census & $\begin{array}{c}\text { Growth Rate of } \\
\text { percent }\end{array}$ & $\begin{array}{c}\text { Growth Rate of } \\
\text { percent }\end{array}$ \\
\hline Year & Urban (PU) Tempo & $\begin{array}{c}\text { Rural (PR) } \\
\text { Tempo }\end{array}$ \\
\hline $1901-1911$ & -1.7300 & 0.0990 \\
\hline $1911-1921$ & 0.7400 & -0.0500 \\
\hline $1921-1931$ & -1.8200 & 0.1000 \\
\hline $1931-1941$ & 3.1500 & -0.2200 \\
\hline $1941-1951$ & 1.5400 & -0.1400 \\
\hline $1951-1961$ & -0.4900 & 0.0400 \\
\hline $1961-1971$ & 0.8000 & -0.0700 \\
\hline $1971-1981$ & 1.7200 & -0.2100 \\
\hline $1981-1991$ & 1.0300 & -0.1400 \\
\hline $1991-2001$ & -0.2200 & 0.0300 \\
\hline
\end{tabular}

Source : Census of India, 2001, Uttar Pradesh, Volume-I, Primary Census

\begin{tabular}{|c|c|c|c|c|c|c|c|c|}
\hline \multicolumn{9}{|c|}{ Table 6} \\
\hline \multicolumn{9}{|c|}{ Number and Population Share of Towns by Size-Classes in Eastern U.P. (1901-2001) } \\
\hline \multirow{2}{*}{$\begin{array}{c}\text { CENS } \\
\text { US } \\
\text { YEAR }\end{array}$} & \multirow{2}{*}{$\begin{array}{l}\text { Number \& population of } \\
\text { town }\end{array}$} & \multicolumn{6}{|c|}{ Size-Classes } & \multirow[t]{2}{*}{ Total } \\
\hline & & I & II & III & IV & $\mathrm{V}$ & VI & \\
\hline \multirow[t]{3}{*}{1901} & No. of Towns & 2 & 3 & 3 & 16 & 29 & 29 & 82 \\
\hline & $\%$ of Towns & 2.44 & 3.66 & 3.66 & 19.51 & 35.37 & 35.37 & 100.00 \\
\hline & $\%$ of population & 31.48 & 16.37 & 8.90 & 18.12 & 17.56 & 7.57 & 100.00 \\
\hline \multirow{3}{*}{1911} & No. of Towns & 2 & 2 & 4 & 11 & 26 & 34 & 79 \\
\hline & $\%$ of Towns & 2.53 & 2.53 & 5.06 & 13.92 & 32.91 & 43.04 & 100.00 \\
\hline & $\%$ of population & 36.27 & 10.73 & 10.76 & 14.60 & 17.57 & 10.06 & 100.00 \\
\hline \multirow{3}{*}{1921} & No. of Towns & 2 & 3 & 3 & 11 & 29 & 41 & 89 \\
\hline & $\%$ of Towns & 2.25 & 3.37 & 3.37 & 12.36 & 32.58 & 46.07 & 100.00 \\
\hline & $\%$ of population & 33.00 & 15.67 & 7.82 & 15.34 & 17.78 & 10.39 & 100.00 \\
\hline \multirow[t]{3}{*}{1931} & No. of Towns & 2 & 3 & 7 & 11 & 33 & 38 & 94 \\
\hline & $\%$ of Towns & 2.13 & 3.19 & 7.45 & 11.70 & 35.11 & 40.43 & 100.00 \\
\hline & $\%$ of population & 29.75 & 15.52 & 14.79 & 11.92 & 18.76 & 9.26 & 100.00 \\
\hline \multirow{3}{*}{1941} & No. of Towns & 2 & 3 & 7 & 11 & 31 & 37 & 94 \\
\hline & $\%$ of Towns & 2.13 & 3.19 & 10.64 & 11.70 & 32.98 & 39.36 & 100.00 \\
\hline & $\%$ of population & 33.20 & 14.43 & 20.08 & 9.39 & 14.99 & 7.90 & 100.00 \\
\hline \multirow[t]{3}{*}{1951} & No. of Towns & 3 & 3 & 11 & 11 & 33 & 36 & 97 \\
\hline & $\%$ of Towns & 3.09 & 3.09 & 11.34 & 11.34 & 34.02 & 37.11 & 100.00 \\
\hline & $\%$ of population & 42.47 & 11.50 & 17.53 & 8.20 & 13.49 & 6.81 & 100.00 \\
\hline \multirow{3}{*}{1961} & No. of Towns & 4 & 3 & 12 & 16 & 17 & 4 & 56 \\
\hline & $\%$ of Towns & 7.14 & 5.36 & 21.43 & 28.57 & 30.36 & 7.14 & 100.00 \\
\hline & $\%$ of population & 55.39 & 9.48 & 18.78 & 9.82 & 5.94 & 0.59 & 100.00 \\
\hline \multirow[t]{3}{*}{1971} & No. of Towns & 5 & 4 & 12 & 24 & 27 & 3 & 75 \\
\hline & $\%$ of Towns & 6.67 & 5.33 & 16.00 & 32.00 & 36.00 & 4.00 & 100.00 \\
\hline & $\%$ of population & 55.20 & 9.86 & 15.43 & 12.11 & 7.16 & 0.23 & 100.00 \\
\hline \multirow[t]{3}{*}{1981} & No. of Towns & 6 & 9 & 17 & 50 & 68 & 16 & 166 \\
\hline & $\%$ of Towns & 3.61 & 5.42 & 10.24 & 30.12 & 40.96 & 9.64 & 100.00 \\
\hline & $\%$ of population & 44.94 & 14.19 & 12.12 & 16.00 & 11.37 & 1.37 & 100.00 \\
\hline \multirow[t]{3}{*}{1991} & No. of Towns & 8 & 12 & 27 & 68 & 62 & 2 & 179 \\
\hline & $\%$ of Towns & 4.47 & 6.70 & 15.08 & 37.99 & 34.64 & 1.12 & 100.00 \\
\hline & $\%$ of population & 48.25 & 14.93 & 13.06 & 15.34 & 8.27 & 0.14 & 100.00 \\
\hline \multirow[t]{3}{*}{2001} & No. of Towns & 14 & 9 & 48 & 94 & 33 & 4 & 202 \\
\hline & $\%$ of Towns & 6.93 & 4.46 & 23.76 & 46.53 & 16.34 & 1.98 & 100.00 \\
\hline & $\%$ of population & 54.61 & 8.25 & 17.09 & 16.58 & 3.25 & 0.22 & 100.00 \\
\hline
\end{tabular}

